\title{
Parliamentary Debate as a Driver of Military Justice Reform in Canada
}

\author{
Preston Jordan Lim
}

\begin{abstract}
In June 2019, the Supreme Court of Canada pronounced judgment in the case of $R v$ Stillman, upholding the military justice system's ability to try serious civil offences. The Stillman decision highlighted one key mechanism of military justice reform: court judgments. This article argues, however, that military legal experts have overlooked Parliamentary debate as a key driver of military reform. By drawing on analysis of Hansard from past decades, this article argues that the Canadian Parliament has historically pushed for radical reform to the military justice system. This reformist consensus continues to shape Parliamentary discussions on military justice in the twenty-first century.
\end{abstract}

Keywords: Stillman, Beaudry, military justice reform, Canadian armed forces, court martial appeal court.

\section{Résumé}

En juin 2019, la Cour suprême du Canada a rendu un jugement dans l'affaire $R$ c. Stillman qui confirmait la capacité du système de justice militaire à juger des infractions civiles graves. L'arrêt Stillman a jeté la lumière sur un mécanisme clé de la réforme de la justice militaire : les jugements des tribunaux. Cet article soutient, cependant, que les experts juridiques militaires ont négligé les débats parlementaires comme moteur essentiel de la réforme militaire. En s'appuyant sur l'analyse du Journal des débats parlementaires canadiens (Hansard) des dernières décennies, cet article soutient que le Parlement canadien a historiquement soutenu des réformes radicales du système de justice militaire. Ce consensus réformiste continue de façonner les discussions parlementaires sur la justice militaire au $\mathrm{XXI}^{\mathrm{e}}$ siècle.

Mots-clés: Stillman, Beaudry, Réforme de la justice militaire, Forces armées canadiennes, Cour d'appel de la cour martiale. 


\section{Introduction}

In July 2019, the Supreme Court of Canada pronounced judgment in the case of $R v$ Stillman, ${ }^{1}$ upholding the military justice system's ability to try serious civil offences. The case addressed a consolidated set of appeals, including an appeal of the Court Martial Appeal Court's ("CMAC") September 2018 decision in $R v$ Beaudry. ${ }^{2}$ Since CMAC's decision, legal commentators have postulated that a Supreme Court affirmation could have resulted in revolutionary changes to Canada's military justice system. ${ }^{3}$

Corporal Beaudry's case revolved around the applicability of Charter rights to service personnel. Section 11(f) of the Canadian Charter of Rights and Freedoms grants persons the right "except in the case of an offence under military law tried before a military tribunal, to the benefit of trial by jury where the maximum punishment for the offence is imprisonment for five years or a more severe punishment." Sections 2 and 130(1)(a) of the National Defence Act ("NDA"), however, define service offences to include acts or omissions "punishable under... the Criminal Code or any other Act of Parliament," thereby sweeping civil offences into the jurisdiction of courts martial. ${ }^{5}$ Judge Vital Ouellette, in delivering CMAC's decision, held that the drafters of the Charter in 11(f) were referring only to military offences, not to civil offences, and that the 11(f) exception would no longer apply for civil offences tried before courts martial. ${ }^{6}$

In a five-two decision, however, the Supreme Court again upheld the existence of a separate military justice system, writing that Section 130(1)(a) of the NDA properly transformed civil offences into service offences and that accused persons did not enjoy an absolute right to a civilian jury. Justices Moldaver and Brown, delivering the majority's opinion, discussed the history of Canadian military law. They noted that ever since the enactment of the NDA in 1950, the Code of Service Discipline, which articulates the complete code of military law, has "contained a provision transforming ordinary civil offences into service offences." "The majority also refused to resurrect the military nexus or service-connection test: under such an approach, a court martial would only have jurisdiction over those offences with a "rational connection to discipline, efficiency, and morale in the military." Instead, Justices Moldaver and Brown held that the only military nexus required to satisfy a military tribunal's jurisdiction over an offence is "the accused's military status."

$R v$ Stillman, 2019 SCC 40 [Stillman].

$R v$ Beaudry, 2018 CMAC 4 at para 53 [Beaudry].

See, for example, Jesse Beatson, “ $R v$ Beaudry: Is Canada's military justice system unconstitutional?" Court, 13 March 2019, http://www.thecourt.ca/r-v-beaudry-is-canadas-military-justicesystem-unconstitutional/; Ken Hansen, "A landmark ruling on military courts means the forces must change for the better," Maclean's, 8 October 2018, https://www.macleans.ca/opinion/alandmark-ruling-on-military-courts-means-the-forces-must-change-for-the-better.

4 Canadian Charter of Rights and Freedoms, Part I of the Constitution Act, 1982, being Schedule B to the Canada Act 1982 (UK), 1982, c 11, s 11(f).

National Defence Act, RSC 1985, c N-5, ss 2, 130(1)(a) [NDA].

Stillman, supra note 1 at para 51.

Ibid at para 74 .

Ibid at para 109 . 
The Beaudry saga highlighted the importance of one mechanism of military justice reform: constitutional rulings. A Supreme Court affirmation of CMAC's holding might well have forced the most significant reforms to the military justice system since the late twentieth century. Yet the Beaudry saga also highlightedalbeit briefly - the importance of Parliamentary debate as a driver of military justice reform. The initial CMAC holding met with Parliamentary debate; James Bezan, the Conservatives' Defence Critic, notably argued that the decision "creates all sorts of difficulties as it relates to good order of discipline and morale within the Canadian Armed Forces." 9 No doubt a Supreme Court affirmation of CMAC's holding would have met with sharper and more prolonged debate.

Despite the momentary excitement that the Beaudry holding inspired, the Canadian legal community has historically paid little attention to Canada's military justice system as a whole. Few authors have written on institutions like CMAC, and even fewer have charted the evolution of the modern military justice system since the 1950 NDA created the Court Martial Appeal Board ("CMAB”), CMAC's predecessor. To understand the current historical moment and contemplate further avenues for reform, it is necessary to first address the question of how the military justice system has changed over time.

This paper will interact with the handful of articles and books that address the Canadian military justice system. As Chris Madsen has argued, the two World Wars propelled the development of a uniquely Canadian system of military justice. During the First World War, the "sense of pride in the achievements of the Canadian Corps...militated against Canada ever again placing its military forces unconditionally under British disciplinary authority." ${ }^{10}$ After the Second World War, Parliament would introduce the 1950 NDA, which, though informed by American and British influences, articulated a distinctly Canadian vision of military justice.

Fewer writers have focused seriously on reforms since 1950. Gilles Létourneau, one of Canada's experts on military justice, masterfully covers the current state of the military justice system as well as significant legislation from the past two decades in his Introduction to Military Justice but fails to properly detail the mechanisms that underlie military justice reform. ${ }^{11}$ A 2017 Draft Internal report by the Court Martial Comprehensive Review Team has done a better job of tracing out the reform process. The report cites three main drivers of reform: (1) Parliamentary legislation, (2) broader "civilian criminal justice system reform requiring consequential amendments" to national defence legislation, and (3) "constitutional rulings from CMAC." 12

9

10 Debates, House of Commons (15 October 2018), 22350.

10 Chris Madsen, Another kind of justice: Canadian military law from Confederation to Somalia (Vancouver: UBC Press, 1999), 51.

11 Gilles Létourneau, Introduction to military justice: An overview of the military penal system and its evolution in Canada (Montreal: Wilson \& Lafleur, 2012).

12 Judge Advocate General, Draft Internal Report: Court Martial Comprehensive Review (Ottawa: Judge Advocate General, 2018), 40, accessed 23 April 2020, https://www.canada.ca/content/dam/ dnd-mdn/migration/assets/FORCES_Internet/docs/en/jag/court-martial-comprehensive-reviewinterim-report-21july2017.pdf. 
Those three drivers are certainly part of the picture. This paper contends, however, that Parliamentary debate has been overlooked as a key driver of the reform process. Other factors-Parliamentary legislation, the influence of the Charter of Rights and Freedoms, CMAC rulings, new military conflicts and operations-are undoubtedly important, but only insofar as they intersect with Parliamentary debate. It is in Parliament that MPs and Senators debate and amend legislation, choose to respond to or ignore national and global developments, and ultimately decide how far to go in reforming the military justice system.

This paper draws on analysis of Hansard from past decades and focuses on three historical periods that saw some of the most radical reform to the military justice system, arguing that Parliamentary debate proved a key catalyst for reform in all three periods. The post-war period (Part I) was marked by an all-party consensus, which held that dramatic military justice reform was necessary. That period resulted most significantly in the 1950 and 1959 NDAs, which notably created the foundations of the modern military appellate system. The two periods of reform since the post-war period have focused less on the military justice system's appellate mechanisms. The second period was the post-Somalia period (Part II), which began in the late nineties and saw a reformist push for improvement of the military justice system. This period also saw a rise in partisan politics, though support for military justice reform essentially remained an all-party affair. The last chronological section (Part III) turns to address the current historical moment by analysing the debates surrounding Bill C-77 and the Beaudry decision. In many ways, the current historical moment is but an extension of the postSomalia period. The paper concludes that, although Parliament has not focused closely on the military justice appellate system since the post-war period, the time is ripe for further reforms to CMAC. The current structure of the court promotes inconsistent decisions and a lack of judicial economy.

\section{Origins of the Modern Military Justice Appellate System}

The 1950 and 1959 NDAs introduced a whole host of military justice measures and, notably, created the foundations of the modern appellate system. The Court Martial Appeal Court was created through the 1959 NDA but traces its origins to the 1950 NDA. Part IX of the 1950 NDA established a "Court Martial Appeal Board, which shall hear and determine all appeals referred to it under this part." ${ }^{3}$ The Parliaments of the 1940s and 1950s, I argue, succeeded in implementing military justice reform because so many MPs had seen military service, a phenomenon which resulted in an all-party push for increased, if not full, civilianization of the military justice system. In the twenty-first Parliament, which passed the 1950 NDA, 105 out of 262 Members of Parliament and 23 out of 102 Senators had seen military service. In the twenty-fourth Parliament, which passed the 1959 NDA, 115 out of 265 Members of Parliament and 33 out of 102 Senators had seen military service. Parliamentary reformist trends manifested not only in the initial creation of 
$\mathrm{CMAB}$, but also in the transformation of CMAB to CMAC, as well as in the military justice reform process writ large.

Before addressing the legislative process, it is worth reviewing the key provisions-particularly the appellate mechanisms-of the 1950 and 1959 NDAs. Clause 190 of the 1950 NDA detailed the organizational structure of CMAB. Subsection 5 specified that "three members of [CMAB] shall be a quorum."14 The Chairman of the Board was to be a "judge of the Exchequer Court or of a superior court of criminal jurisdiction," while the other members could be barristers "of not less than five years standing." ${ }^{15}$ Clause 195 established the rules of appellate procedure, and 196 covered appeals to the Supreme Court. ${ }^{16}$ An accused person could appeal to the Supreme Court only "where there has been dissent in the Board." 17 Today, of course, the accused can appeal to the Supreme Court "on any question of law, if leave to appeal is granted by the Supreme Court of Canada." 18

Legal analysts have already thoroughly covered the 1959 NDA. As Colonel Michel Drapeau notes, the new NDA replaced CMAB with CMAC, the latter being a "superior court of record...composed solely of superior court judges," with jurisdiction that was "essentially the same as that of the board." ${ }^{19}$ Brigadier Jerry Pitzul and Commander John Maguire stress that CMAC still did not have the ability to "entertain severity of sentence applications." ${ }^{20} \mathrm{CMAC}$ only gained powers to review the "severity of sentences" and to "substitute new sentences" in $1991 .{ }^{21}$ While these writers have comprehensively analyzed provisions of national defence legislation, they have failed to focus on the process by which such legislation was amended.

Post-war Canadian Parliaments were filled by men who had served in uniform, during either the First or the Second World War. Those MPs brought to Parliament a keen understanding not only of defence affairs, but also of the shortcomings of the military justice system. As Chris Madsen has noted, British authorities executed a shocking "25 Canadians" during the Great War. During the Second World War, the Canadian Army only executed one soldier, Private Joseph Pringle. ${ }^{22}$ Although Teresa Iacobelli has recently challenged "notions that military law was harsh and inflexible during the Great War," Hansard demonstrates that many veterans in the postwar period tended to paint wartime courts martial as imperfect and unfair. ${ }^{23}$

Ibid at s $190(5)$.

Ibid at s 190(2).

Ibid at s 195-96.

Ibid at s 196(1).

NDA, supra note 5 at s 245(1)(b).

Michael Drapeau, "Canadian military law: Sentencing under the National Defence Act: Perspectives and musings of a former soldier," Canadian Bar Review 82, no. 2 (2003): 432.

20 Jerry Pitzul and John Maguire, “A perspective on Canada's code of service discipline," Air Force Law Review, 52 (2002): 7.

21 Drapeau, supra note 19 at 433.

22 Madsen, supra note 10 at $46,85$.

23 Teresa Iacobelli, Death or Deliverance: Canadian courts martial in the Great War (Vancouver: UBC Press, 2013) 6. 
Members of Parliament with a military service background were often able to draw on personal understandings of the military justice system during parliamentary debates. Co-operative Commonwealth Federation ("CCF") MP Herbert Herridge, for example, who criticized various elements of the proposed 1959 NDA, shared during parliamentary debates that he had almost been "court-martialled on one occasion" during the Great War for failing to properly inspect his men's rifles while serving "in France as a musketry instructor." ${ }^{24}$ Other MPs evidenced similarly personal understandings of the military justice system. Co-operative Commonwealth Federation MP Owen Jones, who had served in both World Wars, declared to the twenty-first Parliament that "many fine men were ruined in both wars by the imposition of unjust punishment." 25 Arthur LeRoy Smith, a Progressive Conservative ("PC"), cited his "considerable experience in defending people before courts martial." ${ }^{26}$ Most significantly, Liberal MP and Minister of National Defence Brooke Claxton had, during the Second World War, written a booklet entitled "Military Law and Discipline for Canadian Soldiers." 27 He emerged as a driving force behind the 1950 NDA. Claxton noted that, during the Second World War, the different military branches had been regulated by different disciplinary acts, and he argued that it was time for "a single code, applicable to all the Canadian armed services." ${ }^{28}$ In sum, many MPs debating the 1950 and 1959 NDAs were able to draw on a deep and personal understanding of the military justice system.

Due to their personal experiences, many post-war MPs pushed for a military justice system that would closely mirror the civilian justice system. On the one hand, some MPs ardently defended wartime courts martial. Julian Harcourt Ferguson, a PC MP who served with the Canadian Expeditionary Force during the Great War, proclaimed that "the percentage would be one-tenth of one per cent where there was a miscarriage of justice dealt out by active service officers." ${ }^{29} \mathrm{On}$ the other hand, Hansard demonstrates that many MPs promoted what by modern standards would appear as a radical vision of military justice reform. The main criticism that MPs of all parties had of the NDAs was not that legislation went too far in civilianizing the military justice system, but that such legislation fell short. Arthur Smith thought that it was "utterly wrong" that a man charged with crimes under the Criminal Code should be tried by officers in the army and not "turned over to the civil authorities," effectively calling for Beaudry-style reform. ${ }^{30}$ Progressive Conservative MP John Hamilton, critical of the death penalty, suggested that a general court martial ought only to be able to impose the death sentence if it came to a "unanimous verdict." ${ }^{31}$ The Canadian military would only abolish the death penalty in 1998.

\footnotetext{
Debates, House of Commons (20 February 1959), 1231.

Debates, House of Commons (16 May 1950), 2549.

Debates, House of Commons (16 May 1950), 2554.

Debates, Senate (8 November 1949), 227.

Debates, Senate (8 November 1949), 226.

Debates, House of Commons (16 May 1950), 2556.

Debates, House of Commons (16 May 1950), 2555.

Debates, House of Commons (25 April 1955), 3143.
} 
This push for more, not less, reform extended also to the debates surrounding the military justice appellate system. Major General George Pearkes, a PC MP, was certainly not alone in welcoming the "opportunity of appeal from the ruling of courts martial." ${ }^{2}$ Yet quite a few MPs saw both CMAB and CMAC as not revolutionary enough. Pearkes noted that an accused appealing a court martial had fewer rights than a "person convicted by a civil court," for he could only appeal to CMAB against the "legality of the finding and sentence." ${ }^{33}$ Progressive Conservative MP Davie Fulton, debating 1955 amendments to the NDA, criticized a provision that would have allowed the chairman of CMAB to delegate his duties to other members of the board. Eight of the ten members of CMAB, after all, were not judges, and Fulton worried that in place of the chairman, the minister might be able to appoint a "man who has had no judicial experience at all." 34

It is also evident that criticism by MPs led to tangible reforms of draft legislation. The government listened to the various calls for increased reform. Commenting on the 1950 NDA, Minister Claxton revealed that the final bill contained some forty-seven "different amendments." Those changes "generally tended to favour the position of the accused, but they are entirely acceptable to the department and to the government." ${ }^{35}$ Parliamentary criticism of CMAB continued throughout the 1950s and undoubtedly influenced the government's decision to create CMAC in 1959. Liberal MP Paul Hellyer, in debates on CMAB's existence and record, hoped that under a new system "there [would] not be the delays which have been experienced in the past." 36 Hellyer brought out a laundry list of complaints, arguing that "it took too long for decisions to be brought down" and that it was "very difficult to secure the attendance of sufficient appointees to constitute a quorum." The transition from an appeal board to a more regular appeal court, Hellyer contended, would make for a more "streamlined" process. ${ }^{37}$

While CMAC certainly introduced welcome, if minor, amendments to the appellate process, it is important to underscore the revolutionary nature of CMAB. By creating an appellate body, albeit one imperfect by today's standards, Parliament established enhanced civilian oversight of what had previously been a closed-off system. On the one hand, Ian Bushnell is correct to point out that the "legal profession" in the 1950s "viewed the military justice system as something special" and as "outside the normal criminal justice system." 38 Yet on the other hand, $\mathrm{CMAB}$, and then $\mathrm{CMAC}$, served important roles in starting to close the gap between the civilian and military justice systems. CMAB was the first and most dramatic manifestation of Parliament's desire to model the military justice system more closely after the civilian system.

Debates, House of Commons (16 May 1950), 2541.

Debates, House of Commons (25 February 1959), 1380.

Debates, House of Commons (25 April 1955), 3149.

Debates, House of Commons (7 June 1950), 3318.

Debates, House of Commons (25 February 1959), 1378.

Debates, House of Commons (20 February 1959), 1231.

38 Ian Bushnell, The Federal Court of Canada: A history, 1875-1992 (Toronto: University of Toronto Press, 1997), 130. 
Moreover, although $\mathrm{CMAB}$ might have been inefficient, few writers have focused enough on the extraordinary makeup of the board. The board, like Parliament, was filled with men who had served in the military and who brought to their duties a deep understanding of military justice. The first volume of the Court Martial Appeal Reports lists nine members: Judge A. G. McDougall, G. A. Addy, B. M. Alexandor, L. C. Audette, L. W. Brockington, M. B. K. Gordon, D. K. MacTavish, Leonce Plante, and the Honourable J. C. A. Cameron, who served as Chairman. ${ }^{39}$ Judge Cameron had served in the Princess Patricia's Canadian Light Infantry during the Great War. ${ }^{40}$ Bushnell notes that George Addy had "considerable military experience." ${ }^{11}$ MacTavish and Gordon could draw on more recent military experience. Duncan MacTavish had served as Deputy Judge Advocate General in the Royal Canadian Navy during the Second World War. ${ }^{42}$ Melville Gordon led the 27th Canadian Armoured Regiment in the field after the Normandy landings and was awarded a Distinguished Service Order. ${ }^{43}$

In case after case, $\mathrm{CMAB}$ proved willing to disagree with the findings of lower courts. Member of Parliament George Pearkes's critical assessment of CMAB quantitatively indicates that the board was no rubberstamp: of fifty-two appeals, the board "disallowed 29, ordered new trials in 14 cases, and allowed six without ordering a new trial." These figures, Pearkes continued, were proof that the "court martial appeal board has made a very substantial contribution toward ensuring that military justice is administered in a fair and impartial manner." 44

\section{The Post-Somalia Reforms}

In 1993, Canadian troops serving in Somalia on a United Nations mission beat and tortured Shidane Arone, a Somali teenager, to death. The resulting scandal resulted in a full, public inquiry and the disbandment of the Canadian Airborne Regiment. The Somalia Commission of Inquiry, headed by Justice Gilles Létourneau, held that "the military justice system in place during the Somalia deployment, and largely still in place today, exhibited serious deficiencies." ${ }^{5}$ Combined with the increasing influence of the Charter as well as former Chief Justice Brian Dickson's separate but comprehensive report ${ }^{46}$ on the state of Canadian military justice, the Somalia affair

39 Canada, Court Martial Appeal Court, Court martial appeal reports, vol. 1 (Ottawa, ON: Court Martial Appeal Board, [1957] 1 CACM at iii.

40 "John Charles Alexander Cameron, Q.C., M.P."” Parlinfo, Parliament of Canada, accessed 23 April 2020, https://lop.parl.ca/sites/ParlInfo/default/en_CA/People/Profile?personId=3682.

$41 \quad$ Bushnell, supra note 38 at 385.

42 "Senator MacTavish in Politics 40 years," Toronto Star, 16 November 1963.

43 Canada, Public Archives of Canada, Gordon, Melville Burgoyne Kennedy (Ottawa, ON: Public Archives of Canada, 1981), http://data2.archives.ca/pdf/pdf001/p000002708.pdf.

44 Debates, House of Commons (25 February 1959), 1380.

45 Canada, Commission of Inquiry into the Deployment of Canadian Forces to Somalia, Report of the Commission of Inquiry into the Deployment of Canadian Forces to Somalia, vol. 1 (Ottawa, ON, 1997), https://qspace.library.queensu.ca/bitstream/handle/1974/6881/somalia_volle.pdf?sequence=5\&isAl lowed $=\mathrm{y}$.

46 Canada, Department of National Defence, Report of the Special Advisory Group on Military Justice and Military Police Investigation Services (Ottawa, ON: Department of National Defence, 1997), https://responsesystemspanel.whs.mil/public/docs/meetings/20130924/materials/allied-forces-miljustice/canada-mj-sys/04_Dickson_Rpt.pdf. 
led Parliament to enact a raft of military reforms, starting in the late 1990s but extending well into this century.

It would, of course, be a mistake to view the period between the 1959 creation of CMAC and the entering into law in 1998 of Bill C-25 as static. Létourneau argues that in the early 1990s, CMAC began to more closely resemble courts of appeal of criminal jurisdiction. ${ }^{47}$ Moreover, as the 2017 Draft Internal report notes, a number of court cases-notably $R v$ Généreux - led to changes related to the "right of accused persons to a fair trial by an independent and impartial tribunal" between 1990 and 1992. ${ }^{48}$ In Généreux, the Court, though affirming the "existence of a parallel system of military law and tribunals," concluded that the General Court Martial system was not compliant with section 11 (d) of the Charter. ${ }^{49}$ Yet it was the late 1990s that saw some of the most significant reforms to the military justice system since the post-war period, in part because the conduct of Canadian soldiers during the Somalia affair so thoroughly shocked Parliament and the wider Canadian public. This section argues that in the post-Somalia period, MPs were able to advance the reformist agenda because of the survival of an all-party consensus on the need for increased civilianization of the military justice system. Reform carried the day despite the lack of MPs with military experience and a rise in partisanship.

Bill C-25, An Act to Amend the National Defence Act, received Royal Assent in December 1998 and sparked a raft of follow-on legislation. ${ }^{50}$ Bill C-25 created the offices of Director of Military Prosecutions and Director of Defence Counsel Services, eliminated the penalties of death and imposition of hard labour, and created the Canadian Forces Grievance Board and the Military Police Complaints Commission. Clause 96 required the Minister of National Defence to present a report on the NDA's provisions and operation within five years. ${ }^{51}$ From 1998 to 2015, Parliament would go on to pass some twelve bills that implemented military justice reform, though some addressed the topic only marginally. ${ }^{52} \mathrm{Bill} \mathrm{C-30}$, which received Royal Assent in 2002, oversaw the consolidation of administrative services of the Federal Court, CMAC, and Tax Court. ${ }^{53}$ Bill C-60 reduced the types of courts martial from four to two. ${ }^{54}$ Bill C-15 introduced reforms to the composition of

47 Létourneau, supra note 11 at 49.

48 Judge Advocate General, supra note 12 at 34.

$49 \quad$ Rv Généreux, [1992] 1 SCR 259 at 295.

50 An Act to Amend the National Defence Act, SC 1988, c 35.

$51 \quad$ Ibid at s 96(2).

52 See An Act to Amend the National Defence Act, the DNA Identification Act and the Criminal Code, SC 2000, c 10; An Act to Amend the National Defence Act (Non-Deployment of Persons Under the Age of Eighteen Years to Theatres of Hostilities), SC 2000, c 13; Canada Shipping Act, SC 2001, c 26; An Act to Amend the Criminal Code and to Amend Other Acts, SC 2002, c 13; An Act to Amend the Criminal Code (Organized Crime and Law Enforcement) and to Make Consequential Amendments to Other Acts, SC 2001, c 32; Court Administration Services Act, SC 2002, c 8 [Bill C-30]; AntiTerrorism Act, SC 2001, c 41; Public Service Modernization Act, SC 2003, c 22; An Act to Amend Certain Acts of Canada, and to Enact Measures for Implementing the Biological and Toxin Weapons Convention, in Order to Enhance Public Safety, SC 2004, c 15; An Act to Amend the National Defence Act, the Criminal Code, the Sex Offender Information Registration Act and the Criminal Records Act, SC 2007, c 5; An Act to Amend the National Defence Act (Court Martial) and to Make a Consequential Amendment to Another Act, SC 2008, c 29 [Bill C-60]; Strengthening Military Justice in the Defence of Canada Act, SC 2013, c 24 [Bill C-15].

53 Bill C-30, supra note 52.

54 Bill C-60, supra note 52. 
courts-martial panels and improved security of tenure for military judges. ${ }^{55} \mathrm{Few}$ of these bills addressed the military justice appellate system in so direct a fashion as had the post-war reforms, though reforms to the military justice system as a whole indirectly improved the health of the appellate system.

Once again, while Létourneau and Drapeau both present a detailed and careful analysis of military justice reforms in the past decade, they have paid considerably less attention to the mechanisms undergirding that reform. Hansard reveals the survival of an all-party commitment to civilianization of the military justice system. In the debates surrounding Bill C-25, for example, both government and opposition MPs stressed the importance of military justice reform. Liberal MP and Minister of National Defence Arthur Eggleton cast the bill as a "revitalization of the Canadian military justice system," noting that the proposed reforms would "more closely align military justice processes with judicial processes applicable to other Canadians." ${ }^{56}$ Liberal MP Hec Clouthier proudly described the bill as the most "extensive package of amendments to the National Defence Act since enactment in the year 1950." 57

As in the post-war period, opposition MPs complained that the government legislation did not go far enough in implementing military justice reform. Members of Parliament notably argued that the government had not adequately adhered to the recommendations of the Somalia Inquiry. Leon Benoit, then a Reform MP, criticized the minister for not establishing the office of "independent inspector general" as the Somalia inquiry had recommended; an inspector general, Benoit continued, would take on the role of "an outsider looking over the shoulders of those who run the military." ${ }^{8}$ Pierrette Venne of the Bloc Québécois ("BQ") wanted the Canadian military justice system to "use civilian judges who are totally independent and without military ambitions." ${ }^{\text {" } 99}$ Progressive Conservative MP John Herron flayed the government for only having fulfilled 80 percent of the Somalia inquiry's recommendations and additionally quipped that the "quality" of reforms was far more important than "mere quantity." 60

Reformist sentiments were not merely the product of the immediate postSomalia moment and continued well into the new century. In the 2015 debate over C-41, which died on the Order Paper, Conservative MP and Parliamentary Secretary to the Minister of National Defence Laurie Hawn emphasized the need to bring the military justice system "more in line with some of the aspects of the civilian justice system with respect to the Criminal Code." ${ }^{\prime 1}$ Liberal MP Keith Martin agreed with the spirit of C-41 and argued that the disparity between the military and civil justice systems had to be "eliminated as much as possible," citing

\footnotetext{
Bill C-15, supra note 52.

Debates, House of Commons (19 March 1998), 5150-51.

Debates, House of Commons (19 March 1998), 5157.

Debates, House of Commons (19 March 1998), 5122.

Debates, House of Commons (19 March 1998), 5142.

Debates, House of Commons (19 March 1998), 5147.

Debates, House of Commons (26 November 2010), 6496.
} 
as problematic the idea that service personnel should be "treated more harshly under a military system than a civilian system." 62

At the same time, however, many MPs, while pushing for increased reform, also defended the need for a separate military justice system. Mario Laframboise, a BQ MP, argued that "military justice must become more like civilian justice," but stressed that the Canadian Armed Forces still had to have "its own justice system." ${ }^{3}$ New Democratic Party (NDP) MP Paul Dewar similarly argued that "there needs to be an understanding of the separate nature of the military in terms of its conduct." 64 Such views would be vindicated five years later in the case $R v$ Moriarity. Justice Cromwell, delivering the judgement of the court, affirmed the separate nature of the military justice system, writing that "it is the common ground that the purpose of the military justice system... relates to assuring the discipline, efficiency and morale of the armed forces." Justice Cromwell refused to "narrow this purpose" or, conversely, to "broaden it." 65 Yet the 2010 debates demonstrate that while many MPs realized the need for a separate military justice system, they concurrently sought to narrow the gap between the civilian and military justice systems.

The post-Somalia string of legislation rarely focused on CMAC and on reforms to the appellate system. While some MPs vigorously debated reforms to the military justice system as a whole, they rarely addressed CMAC reform, especially when compared with their predecessors in the post-war period. A potential reason for this is that since few MPs had a military background, CMAC might have seemed to them an arcane institution. An alternative reason is that CMAC appeared relatively progressive when contextualized within the broader military justice system. While I will argue below that CMAC is in need of further reform, the fact remains that by the 1990s, CMAC resembled, in function if not in structure, other courts of appeal. Conversely, quite a few other aspects of the military justice system-the lack of a designated office of the prosecutor and defence counsel, the rights of the accused and of victims, the security of tenure for military judges-remained glaringly regressive. It is thus unsurprising that MPs during this period chose to focus on the most serious inequities bedevilling the military justice system. It would be a mistake, however, to view the appellate process as entirely separate from military justice reform. Post-Somalia reforms to the rights of the accused or the composition of courts martial panels made the system as a whole fairer, which further narrowed the gap between CMAC and other courts of appeal.

The strength of this reformist trend initially appears surprising in light of two factors: first, the decreased number of MPs who had military service and, second, the rise in partisanship. Compared with the postwar period, the post-Somalia Parliaments had fewer military veterans. In the thirty-sixth Parliament, for example, only twenty-one out of 301 MPs and twenty-one out of 104 Senators had seen military service. By the fortieth Parliament, only twelve out of 308 MPs and eleven

\footnotetext{
62 Debates, House of Commons (26 November 2010), 6497.

63 Debates, House of Commons (26 November 2010), 6520.

64 Debates, House of Commons (26 November 2010), 6517.

$65 \quad R v$ Moriarity, 2015 SCC 55 at para 33.
} 
out of 105 Senators had seen military service. Comparing the forty-third and twenty-first Parliaments, the percentage of MPs with military service dropped from forty to about five, and the percentage of Senators with military service dropped from about twenty-three to less than five.

Unsurprisingly, the small handful of MPs with military service tended to speak up in the post-Somalia debates on new military justice legislation. Reform MP Peter Goldring, who had served as a military police officer with the Royal Canadian Air Force, urged his colleagues to vote against Bill C-25 because "there is clearly much work to be done and in the case of this bill much more legislative drafting to be done." ${ }^{66}$ Liberal MP Kevin Lamoureux, speaking in the debate on Bill C-15, referred to his experiences in the Forces before reading a quote from the Létourneau commission: "Is not the soldier who risks his life for us entitled to at least the same rights and equality before the law as his fellow citizens when he is facing criminal prosecutions?"67

Yet Hansard demonstrates that MPs from all parties and all sorts of backgrounds-not just those who had served-promoted further civilianization of the military system. In the debates surrounding Bill C-25, for example, not one of the MPs quoted above-Eggleton, Clouthier, Benoit, Venne, or Herron-had served in the military. Yet all staunchly advocated for military justice reform. New Democrat MP Nelson Riis suggested that it was modern Canada's distance from war that had led to such reformist views. The "unprecedented period of time since Canada was last involved in a major war," Riis suggested, led people "both inside and outside the military to be less tolerant of any perceived systematic unfairness in the system." 68 In other words, whereas negative experiences of military justice led Canada's postwar Parliaments to force military justice reform, MPs decades later would push for further reform, perhaps paradoxically, because of their distant understandings of war and conflict. Parliament has become more diverse in the decades since the Second World War, but support for military justice reform has remained crosssectional.

Past decades have also seen a sharp rise in partisan politics. Although support for military justice reform has thus far persisted, the rise in partisan politics could derail the reformist consensus in the future. Academics have long grappled with the question of whether partisan politics affect Canadian defence and foreign policy. Brian Bow has contended, for example, that political "parties do matter to Canadian defence policy, but only under certain circumstances, and usually only indirectly." 69 During the post-Somalia period, opposition MPs were often willing to accuse the governing party of neglecting national defence policy, sometimes with hyper-partisan zeal. During the debates over C-25, Jim Hart, a Reform MP, declared that "this Liberal government has shown it is no friend to the Canadian

Debates, House of Commons (10 June 1998), 7945.

Debates, House of Commons (29 April 2013), 16003.

Debates, House of Commons (19 March 1998), 5144.

Brian Bow, "Parties and partisanship in Canadian defence policy," International Journal 64, no. 1 (2008/9): 87. 
Armed Forces or people with military service." 70 Hec Clouthier returned fire: "Reform wanted to reduce funding to the military. Instead of trying to do the job with the tools we need, we would be doing the job with Tonka toys if it were up to Reformers." 71 During the debates over C-15, MP Kevin Lamoureux, instead of addressing the arguments of the Opposition, sarcastically commented on the "affection...between the New Democrats and the Conservatives," complaining "there was a time when the NDP opposed Bill C-15, to the degree that it voted against it going to second reading." 72 Compared with the post-war period then, the post-Somalia period saw a spike in partisan language, lending some credence to the view that party differences over foreign and defence policy, while certainly present during the Cold War, became increasingly clear in the late 1990s.

Yet while MPs often proved willing to snipe at other parties with sarcastic comments and partisan posturing, the cross-party consensus on the need for military justice reform has remained intact. Notably, no single party has emerged as a champion of reforming the military justice system in opposition to the other parties. While MPs were willing to criticize the governing party for not going far enough with reforms, the baseline consensus was that the Canadian military justice system, while separate from the civilian system, ought to mirror the latter to the greatest extent possible. This consensus rendered possible the impressive set of new bills that the thirty-sixth through forty-first Parliaments implemented.

\section{The Current Landscape: Military Justice Reform since 2015}

Military justice reform has continued to feature as a key debate topic in Parliament. Although the Somalia Affair now seems a distant event, the post-Somalia reformist consensus has survived. The opening of the forty-second Parliament in late 2015 marks the beginning of the current historical moment. As Hansard demonstrates, rhetoric during the forty-second Parliament largely resembled that of the late 1990s and early 2000s; in other words, the current historical moment is best viewed as an extension of the post-Somalia wave of reform. Despite an uptick in partisanship, broad support for civilianization of the military justice system has remained intact, with the exception that many MPs interpreted CMAC's Beaudry decision as extreme.

Bill C-77, which received Royal Assent in 2019, represented a reformist piece of legislation in the same heritage as the host of post-Somalia military justice bills. Jeffrey Westman has described the bill as the most "dramatic overhaul of summary trials in our history." ${ }^{\prime 3}$ Clauses 24 and 25 of the bill reformed the summary trial system. Compared with courts martial, summary trials offer fewer procedural protections and deal with "less serious offences." C-77 required "all service offences to be dealt with by way of court martial" and limited the application of the summary trial system "to hearings for service infractions"-minor infractions that do not

Debates, House of Commons (19 March 1998), 5156.

Debates, House of Commons (19 March 1998), 5159.

Debates, House of Commons (30 April 2013), 16086.

Jeffrey Westman, "Bill C-77 and the quiet revolution in military justice," ABlawg, 26 July 2019,

https://ablawg.ca/2019/07/26/bill-c-77-and-the-quiet-revolution-in-military-justice. 
result in a criminal record. ${ }^{74}$ The Act also added a Declaration of Victims Rights to the Code of Service Discipline, granting victims of service offences the right to "information, protection, participation, and restitution in respect of service offences." 75

Members of Parliament passed the bill despite an uptick in partisan bickering. Partisan sniping has been a consistent feature of the forty-second Parliament; in its "Real House Lives" report, The Samara Centre interviewed "54 former MPs" from the forty-first Parliament, many of whom expressed "concern that Canadian politics had entered an age of extreme partisanship." 76 Conservative MPs went to great pains to emphasize that Bill C-77 was a good bill because it pulled so much from past Conservative bills that had died on the Order Paper. Richard Martel, for example, proclaimed "that the Conservatives will always protect victims of crime and make sure they are treated fairly," reminding the House that "it was our Conservative government that created the Canadian Victims Bill of Rights." ${ }^{\text {"7 }}$ Alice Wong, another Conservative MP, likewise shared: "I was a proud member of the Conservative government when we brought in the Victims Bill of Rights."78

Such posturing led Liberal MP Kevin Lamoureux to complain that "virtually from day one when the Conservatives assumed the opposition benches, they have been solely focused on the character assassination of...ministers of this government" and declaring that "this is a government that truly cares about our members who are serving in our Canadian Forces." ${ }^{\text {" T9 }}$ The NDP inveighed against both parties, with Randall Garrison arguing that "our military justice system remains woefully under-resourced no matter whether Liberals or Conservatives have been the government." ${ }^{\prime 0}$ There is little doubt that such partisanship impedes cogent, objective, and candid debate about military justice reform.

Despite the sharp partisan rhetoric, the all-party desire for military justice reform has largely remained intact, even if MPs disagree about the ideal nature and extent of reform. The C-77 debates at least somewhat resembled Parliamentary debates from the postwar period, with government MPs affirming the need for reform and opposition MPs often pushing for more radical changes. Certainly, Conservative posturing with regard to C-77 was at least partly motivated by the admirable desire to associate the party with the extension of due process and legal safeguards to the military justice system. During third reading of the bill, Cheryl Gallant, a Conservative MP, stressed the need for radical appellate reform by calling

74 Canada, Library of Parliament, Parliamentary Information and Research Service, Lyne Casavant et al., "Bill C-77: An Act to Amend the National Defence Act and to Make Related and Consequential Amendments to Other Acts," (Ottawa, ON: Library of Parliament, 2018), https://lop.parl.ca/sites/ PublicWebsite/default/en_CA/ResearchPublications/LegislativeSummaries/421C77E An Act to Amend the National Defence Act and to Make Related and Consequential Amendments to Other Acts, SC 2019, c 71.

76 Samara Centre for Democracy, The real house lives: Strengthening the role of MPs in an age of partisanship, vol. 3 (Ottawa: Samara Centre of Democracy), 6, 23 April 2020, https://www. samaracanada.com/docs/default-source/reports/the-real-house-lives-by-the-samara-centre-fordemoracy.pdf?sfvrsn=b893062f_2.

77 Debates, House of Commons (22 February 2019), 25736.

78 Debates, House of Commons (28 February 2019), 25937.

79 Debates, House of Commons (28 February 2019), 25934.

80 Debates, House of Commons (1 October 2018), 22062. 
for "an amendment that would allow" further rights of appeal "in the case of sentencing arising from a summary hearing that was penal in nature." ${ }^{1} \mathrm{New}$ Democrat MP Gord Johns praised the bill as reflecting modern attitudes towards mental health, while also noting "there are still steps that need to be taken to improve our military justice system." 82 The government proved at least somewhat receptive to these reforms: Minister of National Defence Harjit Sajjan noted that the work of the Standing Committee on National Defence had "led to several amendments," which "will make the bill stronger." 83

Critically, however, such reformist sentiments did not extend to the debates surrounding CMAC's Beaudry holding. New Democrat MP Randall Garrison declared, "I am not going to take a position today on what the proper decision in that case should be," cautioning that such a decision was the "job of the Supreme Court, not politicians." 84 James Bezan, Conservative Defence Critic, was more than willing to speak on the decision, however. Bezan argued that CMAC's holding "creates all sorts of difficulties as it relates to a good order of discipline and morale within the Canadian Armed Forces," citing as problematic the fact that the "civil court system [has] a huge backlog" of cases and would be unable to pick up the extra slack in a post-Beaudry system. ${ }^{85}$ Minister of National Defence Harjit Sajjan said only that the government was "appealing this decision to the Supreme Court," and reiterated the line that "our military justice system is extremely necessary to make sure that the Canadian Armed Forces have the right discipline and morale." 86

Despite MPs' willingness to discuss Beaudry, no party cast CMAC's decision as an example of the gradual civilianization of the military justice system. This could be because MPs viewed CMAC's Beaudry decision as too radical or because MPs intended to wait until a Supreme Court decision to comment on potential reforms to the military justice system. Nevertheless, all things considered, the forty-second Parliament wasted little breath on analyzing the potential consequences of CMAC's holding. Liberal MP Francis Scarpaleggia powerfully articulated the case for reform in 2010 when he argued, "never say that something must be done a certain way just because it always has been done that way." ${ }^{\prime 7} \mathrm{He}$ and other like-minded MPs failed to interpret Beaudry as a potential catalyst for further reform.

A Supreme Court affirmation of CMAC's holding could well have benefitted the military justice system. Of course, the minor reform of introducing civilianslikely Department of National Defence employees-into courts martial of civil offences would cause few ripples in the administration of military justice. The more dramatic reform of shunting cases involving civilian offences to civilian courts, however, could have come with its own benefits. Namely, such a course would allow legal officers in the Canadian Armed Forces to spend more time educating troops in international humanitarian law and international human rights law and in

Debates, House of Commons (28 February 2019), 25938.

Debates, House of Commons (22 February 2019), 25728.

Debates, House of Commons (22 February 2019), 25671.

Debates, House of Commons (1 October 2018), 22064.

Debates, House of Commons (15 October 2018), 22388.

Debates, House of Commons (1 October 2018), 22057.

Debates, House of Commons (30 April 2013), 16116. 
interacting with the rest of the military. That MPs did not discuss the potential benefits of CMAC's decision perhaps indicates some limits on modern-day attitudes towards military justice reform, though the activity of future Parliaments could well prove this hypothesis incorrect.

Ultimately, the Supreme Court upheld the military justice system's ability to try serious civil offences. In light of the Supreme Court's decision, it is unlikely that the post-Beaudry wave of reform that some commentators contemplated in light of CMAC's decision will come to pass, though a future court decision could reignite discussions of reform. In the meantime, the survival of a cross-party consensus on the need for military justice reform means that the forty-third Parliament may well take up the cause of reform.

\section{Conclusion}

As with the post-Somalia moment, debates in the forty-second Parliament, while focused on the topic of military justice reform, tended not to focus on the topic of military justice appellate reform. Once again, the reason for that may be Parliamentarians' focus on other, more pressing challenges within the military justice system. Broadly speaking, CMAC does its job well and certainly is more civilianized in certain key respects than its American counterpart, the United States Court of Appeals for the Armed Forces ("CAAF"). As Eugene Fidell has noted, CAAF's judges are only "appointed to fifteen-year terms," and "little is known about the involvement of the Judge Advocates General" in the judge screening process. ${ }^{88}$ CAAF is also very different structurally from CMAC. CAAF only has five judgesChief Judge Stucky and Judges Ryan, Ohlson, Sparks, and Maggs-all of whom bring a great deal of military experience to the table. In contrast, the judges of CMAC, appointed by the Governor in Council, are drawn from the judge pools of the Federal Court of Appeal ("FCA"), the Federal Court, and the various provincial superior courts. There are currently sixty-seven designated judges. CMAC judges tend not to have military or law enforcement backgrounds. Notable exceptions include Chief Justice Richard Bell, who served as a constable with the RCMP, and Justice Patrick Gleeson, who served as a legal officer with the Canadian Armed Forces. Justice Guy Cournoyer does not have a military background but did serve as co-counsel in the foundational military law case $R v$ Généreux.

Although CMAC has a more apparent civilian makeup than CAAF, it remains an imperfect organization in a number of ways. While Parliament has not radically rethought CMAC's structure since 1959, the military justice appellate system would benefit from further reform. Firstly, CMAC's rather bloated structure does not lend itself to the creation of a consistent body of law. In any given decision, three judges are sitting. But while Chief Justice Bell has been a constant voice in CMAC's decisions, CMAC's structure means that the other two judges hearing appeals change from case to case. Arguably, this has led at times to less than consistent case law. 
Ironically, CMAC's Beaudry holding demonstrates this point to a certain extent, for abiding by precedent would have compelled an opposite holding. Notably, Beaudry is not the first time that Section 130(1)(A) of the NDA has come under scrutiny. $R v$ Private Déry similarly examined the constitutionality of Section 130(1)(A). Judges Cournoyer and Gleason disagreed with the holding of an earlier case, $R v$ Master Corporal D.D. Royes, but noted "we are nonetheless bound to follow it due to the principle of comity or horizontal stare decisis." ${ }^{\text {" }}$ As both Judges noted, CMAC had held in Royes that "charges contemplated under Section 130(1)(A) of the NDA may be heard by a service tribunal even if they arise out of a situation where there is no nexus to the military." 90 Of course, Royes was itself the consequence of an earlier holding; in Royes, Judge Trudel kept with precedent by following "Moriarity CMAC, [which]...held that, correctly interpreted, paragraph 130(1)(a) does not violate section 7 and section 11(f) of the Charter." ${ }^{\text {91 }}$ Abiding by stare decisis in Beaudry would have required CMAC to find 11(f) of the Charter compatible with 130(1)(A) of the NDA, in keeping with both Moriarity and Royes. Stare decisis is universally accepted as an important judicial principle. Lawyers and accused persons should be able to tap into a consistent and regularized body of law. The evolution of law to reflect changing societal mores is an important virtue, but such evolution ought to be incremental, not erratic.

If Parliament turns to re-evaluate CMAC, it might seriously consider narrowing the number of judges. $\mathrm{CMAB}$ got the job done with nine members and CAAF operates with five. The FCA only has eleven full-time judges and four supernumerary judges. Like CMAC, the FCA hears cases all over the country. The case for narrowing the bench becomes even stronger upon consideration of how few cases CMAC hears. The court heard four cases in 2018 and two in 2015. In 2014, a year with more cases, CMAC still issued only eleven decisions. Parliament could easily cut CMAC to resemble FCA in size without any sacrifice of the court's efficacy.

Fewer judges would also mean that CMAC could conduct en banc review, a session in which all the judges of a court hear a case. Obviously, the current situation of sixty-seven judges does not allow for en banc review. Neither the National Defence Act nor the Court Martial Appeal Court Rules articulate any provisions for en banc review. ${ }^{92}$ But if Parliament were to winnow the number of CMAC judges down to a manageable five to ten, it could simultaneously allow for en banc review of particularly complex and troublesome cases. Instituting en banc review would draw CMAC even closer to its appellate counterparts like the FCA. At the very least, Parliament should amend the National Defence Act to provide for a bench of no fewer than five judges if the Chief Judge of CMAC considers the matter to be important for the administration of military justice. Lastly, CMAC is not the only aspect of the military justice system that merits further discussion. Members of

$R v$ Déry, 2017 CMAC 2 at para 87.

Ibid at para 30.

$R v$ Royes, 2016 CMAC 1 at para 14; see also $R v$ Moriarity, 2014 CMAC 1 at paras 16, 105.

"Rules of appeal practices and procedures of the Court Martial Appeal Court of Canada," Court Martial Appeal Court, accessed 23 April 2020, https://www.cmac-cacm.ca/en/pages/law-andpractice/rules 
Parliament might also discuss the further civilianization of the military panel system; as the court noted in Stillman, panels are the military law equivalent of a civilian jury, though "[i]mportant differences distinguish one from the other." ${ }^{\text {"3 }}$

This article has argued that MPs from all parties remain committed to military justice reform. Cross-party support for reform has survived despite the rise in partisan politics and the decreased percentage of MPs and Senators with military backgrounds. If the forty-third Parliament follows the pattern of the post-war period and the post-Somalia period, Canadians can be confident that Parliament will rise once more to the challenge of rejecting the status quo and crafting the military justice system to reflect modern standards of justice. In reforming the military justice system, Parliament ought also to reform the structure of the Court Martial Appeal Court by reducing the number of designated judges so as to allow for a more consistent body of law and en banc review.

Preston Jordan Lim

Yale Law School

limpreston@gmail.com 